doi: 10.15503.jecs2021.2.264.293

\title{
PEDAGOGICAL DESIGN OF THE TECHNOLOGY OF STUDENTS' MULTICULTURAL COMPETENCE AT HIGHER EDUCATION INSTITUTIONS
}

\author{
RUSLAN KRAVETS \\ Department of Ukrainian and Foreign Languages \\ Faculty of Management and Law \\ Vinnytsia National Agrarian University \\ 3 Soniachna, Vinnytsia, 21000 Ukraine \\ E-mail address: krawezj@ukr.net \\ ORCID: https://orcid.org/0000-0002-7459-8645

\section{VIRA VYKHRUSHCH} \\ Department of Pedagogy and Innovative Education \\ Institute of Jurisprudence, Psychology and Innovative Education \\ Lviv Polytechnic National University \\ 12 Bandera, Lviv, 79013 Ukraine \\ E-mail address: nazarenkovira@i.ua \\ ORCID: https://orcid.org/0000-0003-3469-2343
}

\section{OKSANA ROMANYSHYNA}

Department of Informatics and Methods of its Teaching

Faculty of Physics and Mathematics

Ternopil Volodymyr Hnatiuk National Pedagogical University

2 Maksym Kryvonis, Ternopil, 46027 Ukraine

E-mail address: oks_roman@ukr.net

ORCID: https://orcid.org/0000-0002-2887-5023

\section{MYKHAILO KOZIAR}

Department of Practical Psychology and Pedagogy

Institute of Psychology and Social Security

Lviv State University of Life Safety

35 Kleparivska, Lviv, 79007 Ukraine

E-mail address: mykhaylo.kozyar@gmail.com

ORCID: https://orcid.org/0000-0001-7068-598X 


\title{
HANNA RIDKODUBSKA
}

Department of Social Work and Social Pedagogy

Humanitarian-Pedagogical Faculty

Khmelnytskyi National University

11 Instytutska, Khmelnytskyi, 29016 Ukraine

E-mail address: anutabanditka1@ukr.net

ORCID: https://orcid.org/0000-0003-0561-6835

\section{IVAN MARIONDA}

Department of Physical Training, Faculty of Healthcare

Uzhhorod National University

29 Mytna, Uzhhorod, 88000 Ukraine

E-mail address: ivan.marionda@uzhnu.edu.ua

ORCID: https://orcid.org/0000-0002-3950-8202

\section{EDUARD SYVOKHOP}

Department of Physical Training, Faculty of Healthcare

Uzhhorod National University

29 Mytna, Uzhhorod, 88000 Ukraine

E-mail address: sivokhop@gmail.com

ORCID: https://orcid.org/0000-0001-8939-8446

\begin{abstract}
Aim. The aim of the research is to justify the theoretical and methodological bases of multicultural education and verify experimentally the efficiency of the pedagogical technology of forming students' multicultural competence at higher education institutions.

Methods. The study reviews the changes in the levels of students' multicultural competence. The methodological bases of the study are theories of language multicultural education, the unity of language and culture, multi-perspective learning, "cultural differences," social learning, neo-Freudian theory, self-determination theory, developmental learning theory.

Results. The realisation of the ideas of multiculturalism has a positive effect on the harmonious development, cultivates a tolerant attitude to other ethnic groups and peoples, promotes good neighbourly relations, effective conflict resolution, intercultural dialogue and mutual understanding. Acquiring these characteristics, students entirely understand national and universal values, and are able to interact constructively in the modern multicultural world at a sustainable level.

Conclusion. The implementation of the developed pedagogical conditions and the author's pedagogical technology of forming students' multicultural competence at higher education institutions contributed to a significant increase in the levels of their multicultural competence. This was confirmed by statistical changes in the level of students' multicultural competence of the experimental group compared to the control group: the number of students with stable (by 34.3\%) and situational (by 12.7\%) levels
\end{abstract}


significantly increased, the number of students with fragmentary level decreased (by $47 \%$ ). Thus, the obtained results prove that the developed pedagogical technology is effective for forming students' multicultural competence.

Key words: professional training, multicultural education, multicultural competence, pedagogical technology

\section{INTRODUCTION}

$\mathrm{T}$ The main components of the system of multicultural education of students - methodological, theoretical and practical - contribute to the implementation of the key idea of the scientific work: the formation of a future specialist's multicultural personality is a priority of educational policy of the state for developing a self-sufficient, tolerant, highly educated, competent, cultural, competitive citizen with a democratic worldview, able to interact constructively in the modern multicultural world. Existing pedagogical, cultural, information-technological and socio-political factors determine the need in multicultural education of students of HEIs.

Pedagogical factors are consistent with the modernisation of the Ukrainian system of higher education due to the integration processes, the creation of an integrated single European educational space and strengthening the humanistic and sociocultural orientation of education, the introduction of innovative pedagogical technologies, enlargement of the educational space's possibilities and HEIs' creative potential, education based on the values of mutual respect and courteous attitude towards other people.

Cultural factors reflect the pro-European aspirations of citizens, the confession of the civil society's values, which puts forward new demands for the formation of a positive national identity and harmonious coexistence in cultural diversity.

Information-technological factors are associated with rapid scientific progress. We consider them through the prism of enlarging the range of applications of information-communication technologies in various fields of the education and the society in general, which in its turn enables online communication with colleagues from different countries all over the world and opens access to a large amount of professional and sociocultural information.

Socio-political factors are transformations in the public life of the country, which motivate young people to act in a certain way in accordance with their own guidelines. They reveal the dialectical relationship between preserving one's identity and joining the world community, finding a common language to establish a constructive dialogue of cultures.

The scientific and theoretical principles, purpose of the work, specifics of forming future specialists' multicultural competence have led to the definition of conceptual principles of the research that needs substantiation at the methodological, theoretical and practical levels. 


\section{TECHNOLOGY OF FORMING STUDENTS' MULTICULTURAL COMPETENCE}

It has been determined that providing students' multicultural education will be successful if the pedagogical technology of forming students' multicultural competence is applied and for its efficiency the following pedagogical conditions are created: implementing the interactive teaching methods for increasing the internal motivation of educational activity; the organisation of the educational multicultural environment as the social system of a multi-subject type at a higher education institution; improving forms and methods of independent work; application of electronic educationally-methodological complex of forming future specialists' multicultural competence (Kravets, 2017).

The experimental research work was conducted from 2012 to 2017 within the Agronomic Faculty of Vinnytsia National Agrarian University, the Hydrometeorological Faculty of Odesa State Environmental University, at the Separated Subdivision of National University of Life and Environmental Sciences of Ukraine "Berezhany Agrotechnical Institute," the Faculty of Agricultural Technologies and Ecology of Tavria State Agrotechnological University. 496 students participated in the experimental work.

In the historical-pedagogical retrospect, the essence of the concept "culture" is considered from the viewpoint of the Enlightenment (the process of developing the human mind, as opposed to the primitiveness of the primordial humanity), classical idealism (historical development of human spirituality evolution of moral, ethical, aesthetic, religious, philosophical, scientific, legal and political consciousness, which ensures the progress of mankind), romanticism (overcoming the conflict between physical and spiritual life, strengthening the unity of the sensorial and the rational in the process of education), neo-Kantianism (an autonomous system of values and ideas, which determine the type of social organisation), modernism (everyday reality, which has a latent content) and postmodernism (a set of material and spiritual values reflecting the level of historical development achieved by the mankind).

It was ascertained that the diversity of approaches to the interpretation of culture is caused by the interdisciplinary nature of this phenomenon.

The analysis of the culturological paradigm of education in the professional training of students of HEIs has made it possible to specify the set of theoretical provisions, which are the basis of the main conceptual ideas and approaches to the problem. Culture is viewed as an anthropological phenomenon, the product of an extremely rich subjectivity of the individual, the disclosure of all human nature in the full variety of its high and low manifestations (Bakhtin, 1986). We regard it as a form of communication (dialogue) between representatives of different cultures, considering it necessary to involve students purposefully in "great dialogues" that unfold in culture and are the core mechanism of spiritual development.

The culturological paradigm of education is one of the ways to form educated, comprehensively developed, highly qualified, competitive specialists in 
the agricultural sector. A significant place in this process belongs to language, because the people's mentality, mindset, spirit and style of thinking manifest themselves in it (Kravets, 2019).

In the result of the establishment of philosophical views on the personality as the highest value of the society the humanisation and humanitarianisation of higher education serve for strengthening the culturological paradigm in the professional training of future specialists. After all, humanisation and humanitarianisation exist in an indivisible unity, complementing each other.

An important role in forming the future specialist's culture is attached to multicultural education, aimed at ensuring the cultural and social identity of the personality, i.e. forming of the multicultural competence. Multicultural education provides involving future specialists in discovering national and world cultures, in forming the ability and readiness to live in the multinational environment on this basis. One of the main tasks of such education is the upbringing of the spiritual culture of the personality, which is clearly manifested during the interaction of ethnophores (Ivaniuk, 2016). There are four guidelines: socio-cultural identification of the personality, mastering the system of concepts and ideas about the multicultural environment, fostering a positive attitude to a diversified cultural environment, the development of multicultural communication skills.

By analysing the scientific works of the researchers (Banks, 2006; Dolzhenko, 2006; Honcharenko, Zubenko, \& Kuzmenko, 2007; Kendzor, 2017; Lynch, 1986; Vorotniak, 2008; Vykhrushch-Oleksiuk, 2016; Zhorniak, 2011), six stages of cultural identity of students have been defined: psychological captivity, encapsulation, recognition of affiliation, biculturalism, multiculturalism and reflexive nationalism, globalism and multicultural competence.

At the stage of psychological captivity, persons demonstrate negative beliefs and ideology about their cultural group. As a result, they have low self-esteem and cultural self-denial. The stage of encapsulation is characterised by a clear awareness of own cultural identity and the person's interaction, mainly only with his/her cultural group, which $\mathrm{h} / \mathrm{she}$ puts above all others. At the stage of recognition of affiliation, the future specialist has sufficient knowledge and skills to make adjustments in the understanding of personal attitudes and cultural affiliation. At the stage of biculturalism, future specialists can interact effectively in two cultural areas: there is a desire to join not only their own, but also other cultural environments. Awareness of their own cultural affiliation is also supported by appropriate knowledge and skills, i.e. the formed cognitive component. The next stage is multiculturalism and reflexive nationalism. Essential indicators are the thoughtful positive cultural and national affiliation of a student to several cultural communities which interact as one nation. The future specialist with such level of the multicultural competence independently determines, evaluates and comprehends the orders and attributes of these cultures, clearly understands their advantages and shortcomings. The highest stage of cultural identity is globalism, or multicultural awareness (competence), when future specialists are able to demonstrate not only a posi- 
tive and thoughtful national-cultural, but also global affiliation. The key point is the affirmation of individual values, which are based on the universal values of mankind, moral norms and ethical principles.

Future specialists, who have mastered the last two stages, will be able to adapt quickly to work and live in a heterogeneous society. The implementation of this task is entrusted to multicultural education. As a result of the analysis of modern national and foreign literature, it has been established that future specialists' multicultural competence is a personality's integrative quality, which includes multicultural knowledge, skills, professional and personal motives, values, experience, rules of conduct, social norms.

"History of the Ukraine's Statehood," "Ethnocultural Studies," "Philosophy," "Business Ukrainian Language," "Foreign Language," "Legal Culture" have been chosen among the disciplines of students' professional training as the disciplines, in whose contents the opportunities for forming future specialists' multicultural competence are embodied.

On the basis of the empirical experience, in addition to the general didactic principles, the specific principles of future specialists' multicultural education have been distinguished and used: the dialogue of cultures, the cultural conformity, the unity of national and universal, the multiculturalism and multicultural tolerance, the dominance of problematic cultural tasks, authenticity, the principle of novelty, the principle of professional orientation (Kravets, 2015).

The choice and professional implementation of pedagogical technologies determine the didactic process efficiency. The focus on the technological approach in the practical application of the arsenal of pedagogy involves a certain manufacturability of teaching forms and methods in terms of their structure, modelling and design of the educational process - outlining the pedagogical goal.

The pedagogical technology of forming students' multicultural competence is scientific designing and reproduction, which guarantees the success of pedagogical actions. It provides for a specially organised goal-setting which enables objective control of the quality of multicultural education; preliminary design of the educational process, with further implementation of this project in practice; a choice of optimal forms, methods and means of forming the multicultural competence of future specialists; organising prompt feedback, which enables timely and quick adjustment of the pedagogical process (Kravets, 2017).

The structural-functional model of the pedagogical technology of forming students' multicultural competence is presented in Fig. 1.

The main structural components of the pedagogical technology are: conceptual, substantive and procedural.

The conceptual component is a scientific basis, i.e. psychological and pedagogical ideas and a well-grounded concept of the multicultural education, which are its foundation. The substantive component contains training tasks (general, specific), the content of the educational material aimed at forming students' multicultural competence. The procedural component includes the organisation of the pedagogical process; methods and forms of organising the 


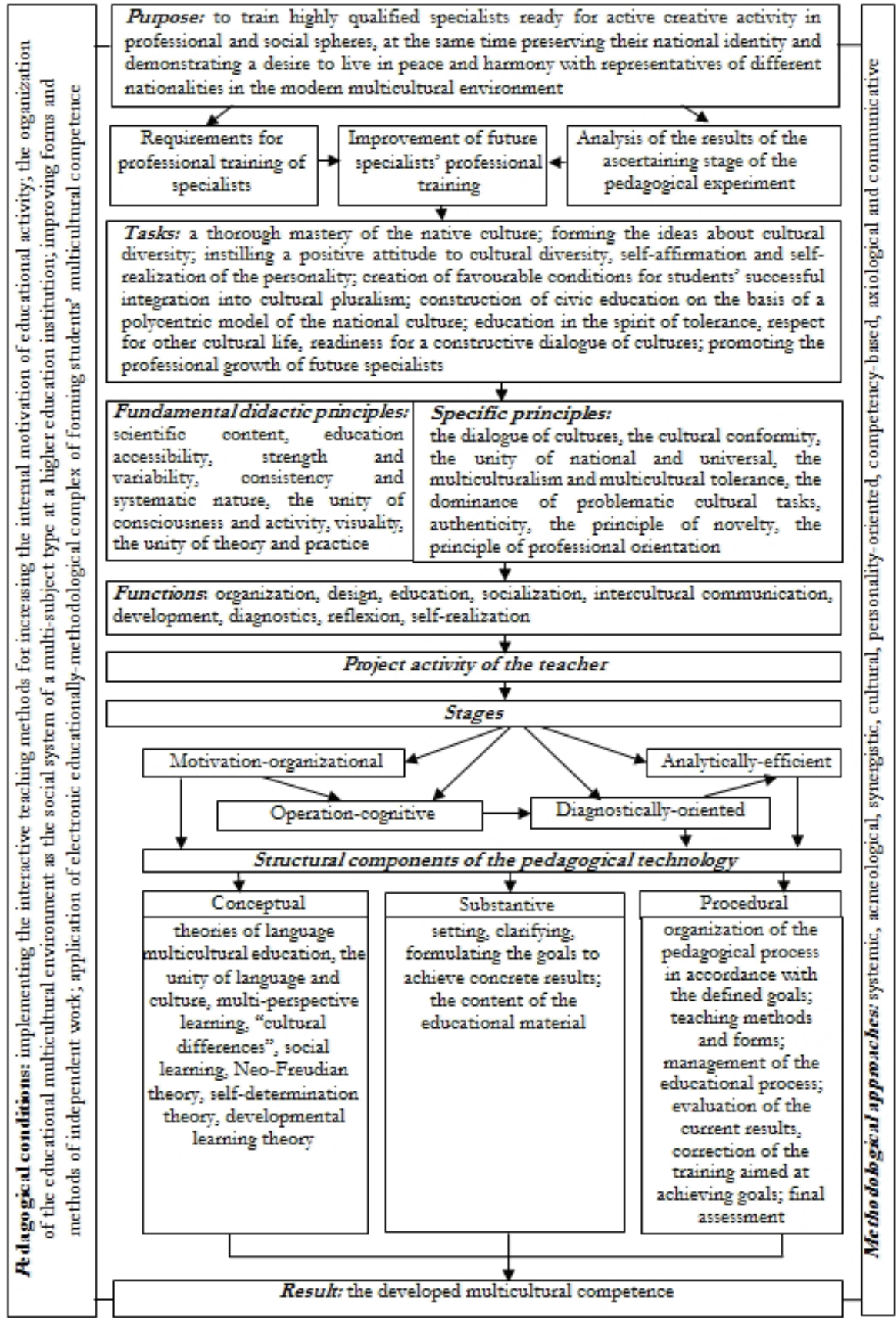

Fig. 1. Structural-functional model of the pedagogical technology of forming student's multicultural competence.

Source: own research 
educational-cognitive activities that contribute to the formation of the multicultural competence and skills of constructive intercultural communication by foreign language means; monitoring the development of the multicultural competence.

Taking into account the main components of educational activity, the stages of implementing the pedagogical technology of forming students' multicultural competence have been determined: motivation-organisational, operation-cognitive, diagnostically-oriented, analytically-efficient. Each of these stages is characterised by certain peculiarities and specific tools and methods.

\section{PEDAGOGICAL EXPERIMENT AND VERIFICATION OF THE RESULTS}

Verification of the efficiency of the pedagogical technology of forming students' multicultural competence was carried out in three stages (determinative, formative, control) within the Agronomic Faculty of Vinnytsia National Agrarian University, the Hydrometeorological Faculty of Odesa State Environmental University, at the Separated Subdivision of National University of Life and Environmental Sciences of Ukraine "Berezhany Agrotechnical Institute," the Faculty of Agricultural Technologies and Ecology of Tavria State Agrotechnological University during 2012-2017.

The content and structure of the authorial electronic educationally-methodological complex of forming future students' multicultural competence were substantiated. The electronic educationally-methodological complex covers normative documents, curriculum, educational-methodical and methodical textbooks, methodical recommendations, the course of lectures, educational programmes, didactic materials, presentations, test tasks, tables, diagrams, terminology guide, cards with individual tasks, audio and video coverage of students' vocational activities.

The essence of experimental training in the practice of HEIs reveals itself in the organisation of multicultural education at "Foreign Language," "History of the Ukraine's Statehood," "Ethnocultural Studies," "Philosophy," "Business Ukrainian Language," "Legal Culture" classes on the basis of the systemic, acmeological, synergistic, cultural, personality-oriented, competency-based, axiological and communicative approaches. Thus, in multicultural education, the relationship of language, culture and professional orientation, taking into account the individual psychological, psychophysiological, social specifics of future specialists, are clearly traced.

The following activities were presented at the foreign language lessons: the theme "English as a means of international communication" with the help of specially developed exercises on the principle of "round table," "What gives a language global status?", brainstorming "Political system of the United Kingdom," round table "Multicultural cities," lecture-dialogue "Basic concepts of Ethnocultural Studies: Ethnic - Ethnicity, Ethnic - Folk - Traditional - National 
Culture," etc. At lectures on the history of the Ukraine's statehood, the following enjoy a great popularity: the lecture-concert on the topic "State-making traditions in the territory of Ukraine in the ancient times," lecture-dialogue "Ukrainian national struggle: Cossack-Hetman state," and round tables "Revival of the idea of Ukrainian national self-determination in the nineteenth century," "Kyiv Rus in the Ukrainian and world history." Lectures and press conferences "Language and speech in the life of people and society," lecture-visualisation "Ukrainian Language - the official language of Ukraine, the national language of the Ukrainian People" and others were held at the Ukrainian language classes. At the legal culture classes we used lectures-consultations to present topics "The concept of legal culture, its functions," "Content of legal culture" and others.

On the basis of the conducted research the pedagogical conditions of forming students' multicultural competence have been determined: implementing the interactive teaching methods for increasing the internal motivation of educational activity; the organisation of the educational multicultural environment as the social system of a multi-subject type at a higher education institution; improving forms and methods of independent work; application of electronic educationally-methodological complex of forming students' multicultural competence.

The results of the formative stage of the experiment are shown in Fig. 2.

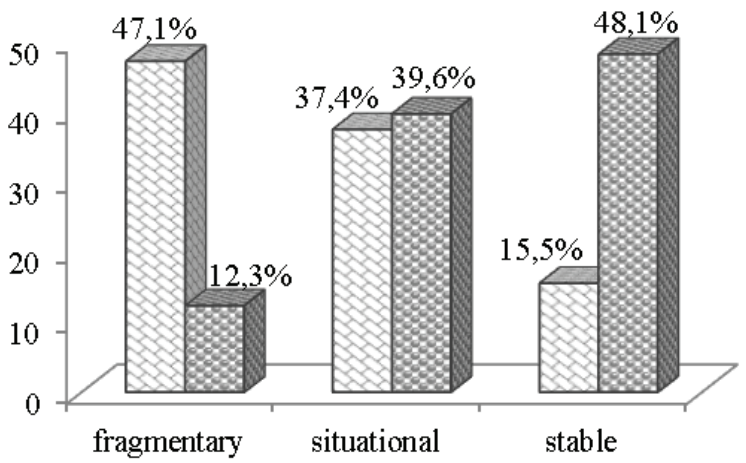

$\square$ Control Group

Gexperimental Group

Fig. 2. Distribution of CG and EG students after the formative stage of the experiment. Source: own research.

According to the obtained data, it can be concluded that at the fragmentary level the number of participants in the experimental group is much smaller (by $34 \%$ ), whereas is larger at the stable level (by 32.6\%).

At "the motivation-organisational stage," the first pedagogical condition for improving the efficiency of pedagogical technology of forming students' multicultural competence was applied - implementing the interactive teaching methods for increasing the internal motivation of educational activity. 
"The operation-cognitive stage" is the process of direct acquaintance with the specificity of cultures of other countries. Its main purpose is to provide students with understanding of the essence of cultural processes, to appreciate culture as a constituent part of the system of interconnected components. It envisages the acquisition by the students a sufficient level of multicultural competence, which will enable them to fulfil successfully their professional obligations in the context of our country's cultural integration into the world community. The operation-cognitive stage covered linguo-social and cultural topics. Discussions, role-playing games, collage, round tables, training "Fundamentals of creative writing," a collective notebook, conversations, social projects, polls, cultural expeditions, dialogues, excursions, festivals, virtual travels to European countries were chosen as the main methods.

At "the diagnostically-oriented stage" a significant role was played by writing creative projects, press conferences, presentation of abstracts, improvisation in intercultural interaction, debates, Socrates' heuristic dialogue, the method of "brainstorming," the method of individual "brainstorming," the method "an inventor's monologue," Tim Eiloart's Questions' Technique Control, random selection of words, the method of gallery, progressive abstraction, Edward de Bono's Six Hats method, discussions about cultural differences and peculiarities. In this case, generalisation, systematisation and correction of the formed professional knowledge, skills and capacities take place. The tasks of the diagnostically-oriented stage are the following: to identify the volume, depth and quality of the multicultural awareness; to find out knowledge gaps and outline ways to eliminate them; diagnosis of the students' degree of responsibility.

"The analytically-efficient stage" involved the use of interactive teaching methods, participation in conferences, questionnaires for estimating multicultural experience. The leading role was played by the pedagogical condition - application of electronic educationally-methodological complex of forming students' multicultural competence, first of all, video and audio materials, the Euro quiz, electronic testing, which made it possible to evaluate accurately the students' multicultural competence.

Statistical verification of the objectivity of the obtained results in the researched groups was performed by using the criterion of reliability of differences in the average values - Student's t-test for independent samples t-test for Independent Samples. The purpose of this verification was to determine whether there were significant differences in the results of forming multicultural competence forming the EG and CG students' multicultural competence. It was assumed that for the significance level $\alpha=0.01$ the differences in the obtained results of the experimental and control groups will be significant, and the null hypothesis $\mathrm{H}_{0}$ is rejected is denied. If $t_{\text {ex. }}$ less than $t_{\text {cr. }}$ (where $t_{\text {ex. }}$ is the result of mathematical data processing, and $t_{\mathrm{cr}}$ is a critical value), then the null hypothesis is accepted, this means that the recorded differences of the results obtained in the experimental and control groups are caused by random factors. If $t_{\text {ex. }}$ is more than $t_{\text {cr. }}$ it testifies to efficiency of the pedagogical technology of forming students' multicultural competence. 


\section{IMPACT OF THE PEDAGOGICAL TECHNOLOGY ON THE DEVELOPMENT OF THE MULTICULTURAL COMPETENCE}

Verification of the efficiency of the pedagogical technology of forming students' multicultural competence was carried out in three stages (determinative, formative, control) within the Agronomic Faculty of Vinnytsia National Agrarian University, the Hydrometeorological Faculty of Odesa State Environmental University, at the Separated Subdivision of National University of Life and Environmental Sciences of Ukraine "Berezhany Agrotechnical Institute," the Faculty of Agricultural Technologies and Ecology of Tavria State Agrotechnological University during 2012-2017.

In order to analyse the dynamics of forming students' multicultural competence at the control stage of the pedagogical experiment, the main criteria and indicators of this quality were re-diagnosed among second-year students using the same methodological tools. We compared the diagnostic results before and after the formative stage of the experiment. The students of the experimental group showed significant positive changes in the indicators of the multicultural competence, which was confirmed by the mathematical statistical tools. A significant increase of students with situational and stable levels, a decrease in the number of students with a fragmentary level of the multicultural competence in EG can be explained by the efficiency of the developed pedagogical technology. In the control group there is a shift in the characteristics of spiritual culture and national self-consciousness (system of knowledge about certain components of the national culture, abilities for cultural self-development and self-determination in the multicultural world, correct perception of cultural values of the studied language; a positive attitude towards the national community; a desire to speak a foreign language, etc.) were insignificant.

At "the fragmentary level" students demonstrate fragmentary, unsystematised sociocultural knowledge; they do not have background knowledge (sociocultural background of the foreign language communication, linguistic knowledge, knowledge of the language mentality formed by sociocultural stereotypes of the language and non-language behaviour); their socio-cultural skills are not formed. Students are characterised by insufficient understanding of socio-cultural values; their abilities for cultural self-development and self-determination in the world of multicultural values are not formed, social and creative orientations are weakly expressed; undifferentiated assessment of representatives of other national cultures, a low level of readiness for intercultural communication, multicultural interaction, dominance of self-esteem over respect for the other people's dignity, indifferent perception/assessment of the culture of the studied language. They have insufficient readiness for intercultural communication in a foreign language. They have no experience of multicultural interaction with representatives of different cultures. Tolerance and empathy are poorly developed. Skills of positive interaction with representa- 
tives of different cultures are absent. Positive motivation to master the socio-cultural knowledge does not manifest itself.

"The situational level" indicates cognitive-gnoseological, motivational-value, personality and operation-effective components of the multicultural competence. Students have the necessary multicultural background knowledge for intercultural communication. They situationally apply them in practice during multicultural interaction. There is a positive trend towards situational understanding of socio-cultural values. The ability for self-development and self-determination of the multicultural personality of the future specialist in the world of cultural values is partially formed. Social and creative orientations depend on the personal significance of the situation. Positive, situational assessment of other national cultures' representatives, an average level of readiness for intercultural communication, unstable ratio of self-esteem and respect for the dignity of others make themselves felt; adequate perception of foreign culture appears. Students show partial ability of multicultural interaction with representatives of different cultures, well-developed qualities such as empathy, tolerance, situational readiness to communicate in the language of international communication. However, the differentiated attitude to the national community is not yet sufficiently formed. They express a situational desire to communicate in a foreign language more often.

"The stable level" is typical for students who: show diverse and systematized socio-cultural knowledge of spiritual and national cultures to the to the full extent; have a stable multicultural background of foreign language communication, thorough knowledge of the language mentality; realise belonging to a certain national community, demonstrate systematic knowledge of individual components of national culture and culture in general, stable ideas about language, culture, typical features of their community, historical past, religion, territory and statehood; use vocabulary with linguistic colouring in foreign language communication. They have a stable ability for multicultural self-development and self-determination in the world of cultural values. They evaluate themselves as representatives of a certain nation, showing a stable creative social orientation; unconditional acceptance of the nation's lifestyle; stable, valuable and respectful attitude to other cultures; correct perception and appreciation of the culture whose language they study. Students demonstrate strong readiness for intercultural communication in a foreign language, skilfully applying knowledge of the language mentality in practice and building multicultural interaction on the basis of empathy and tolerance. A positive attitude towards national and foreign communities is attributive. Students are constantly striving to establish a dialogue of cultures by means of the language of international communication.

Considering the essential characteristics and levels of the multicultural competence, we diagnosed its main indicators. The level of the cognitive-gnoseological component of the multicultural competence was clarified with the help of "English Culture Tests," tasks for identifying socio-cultural and 
linguistic knowledge, existing stereotypes about language and non-language behaviour, understanding of life, traditions, customs, life of the people, relevant for intercultural communication. To determine the level of the personal component we used Vasyl Riakhovskyi's "Test of the General Level of Partnership" (Karelin, 2007); Albert Meierabian's and Michael Epstein's questionnaire for diagnosing the ability to empathize (Fetiskin, Kozlov, \& Manuilov, 2002), express-questionnaire "Tolerance Index" (Soldatova, Shaiherova, Kravtsova, \& Khukhlaieva, 2008), methods of assessing the culture type (Pochebut, 2012). "Diagnostics of Motivational Orientations in Interpersonal Communication," developed by Ivan Ladanov and Valentyna Urazaieva, served as a methodological tool for identifying the level of formation of the motivational-value component (Fetiskin, Kozlov, \& Manuilov, 2002), method "Value Orientations" developed by Milton Rokeach (Karelin, 2007), test-questionnaire for diagnosing the structure of educational motivation (Derbenova, 2012), questionnaires "Foreign Language as an Academic Discipline" and "Motivation to Learn a Foreign Language" (Samarina, 2016). As the main diagnostic tool of the operation-effective component of students' multicultural competence we have developed test tasks to study their ability to analyse, associate, compare socio-cultural phenomena of native and English cultures. The ability of students to function successfully in real situations of multicultural interaction was tested using a questionnaire to determine the multicultural experience: "Multicultural Experiences Questionnaire" (Narvaez \& Patrick, 2010), a test questionnaire "Dependence-Autonomy" developed by Gennadii Prigin (Rean, 2001), the questionnaire of socio-cultural identity (QSCI) developed by Olha Krupenko and Olha Frolova (Tatarko \& Lebedeva, 2011), the questionnaire to identify readiness for intercultural dialogue.

Having compared and analysed the results of diagnostics of students at the determinative, and control stages, we saw a positive dynamics in the development of the multicultural competence in indicators of the cognitive-gnoseological component (Table 1). It is worth noting that the percentage levels for each component in the control and experimental groups differ little. This indicates that at the beginning of the experiment, the control and experimental groups were homogeneous.

Table 1

Levels of students' multicultural competence by the cognitive-gnoseological component in the process of the formative stage of the experiment

\begin{tabular}{|c|c|c|c|c|c|c|c|c|c|c|c|c|}
\hline Levels & \multicolumn{4}{|c|}{ Fragmentary } & \multicolumn{4}{|c|}{ Situational } & \multicolumn{4}{|c|}{ Stable } \\
\hline \multirow[b]{2}{*}{ Group } & \multicolumn{2}{|c|}{ Before } & \multicolumn{2}{|c|}{ After } & \multicolumn{2}{|c|}{ Before } & \multicolumn{2}{|c|}{ After } & \multicolumn{2}{|c|}{ Before } & \multicolumn{2}{|c|}{ After } \\
\hline & $\begin{array}{c}\text { Stu- } \\
\text { dents }\end{array}$ & $\%$ & $\begin{array}{c}\text { Stu- } \\
\text { dents }\end{array}$ & $\%$ & $\begin{array}{l}\text { Stu- } \\
\text { dents }\end{array}$ & $\%$ & $\begin{array}{c}\text { Stu- } \\
\text { dents }\end{array}$ & $\%$ & $\begin{array}{l}\text { Stu- } \\
\text { dents }\end{array}$ & $\%$ & $\begin{array}{c}\text { Stu- } \\
\text { dents }\end{array}$ & $\%$ \\
\hline CG & 177 & 71.6 & 145 & 58.7 & 60 & 24.3 & 83 & 33.8 & 10 & 4.1 & 19 & 7.5 \\
\hline EG & 184 & 73.8 & 29 & 11.8 & 56 & 22.5 & 130 & 52.3 & 9 & 3.7 & 90 & 36.1 \\
\hline
\end{tabular}

Source: own research. 
The numerical indicators showed that after the formative stage of the pedagogical experiment the students significantly improved their knowledge of social and cultural stereotypes, verbal and non-verbal behaviours, linguistic knowledge, systematised knowledge of national culture. Students advanced their knowledge about "English traditions and culture," "Multicultural places," "Landmarks of Great Britain" and others. At the determinative stage of the experimental work in the EG, the stable level of the cognitive-gnoseological component was diagnosed in $3.7 \%$, situational $-22.5 \%$, fragmentary $-73.8 \%$, the results of the control stage showed a decrease in a number of students with the fragmentary level to $11.6 \%$ and an increase in a number of respondents with the situational $(52.3 \%)$ and stable $(36.1 \%)$ levels.

In general, in the process of comparing qualitative and correlation analyses before and after the formative stage of the experiment, all students noted the filling of information and language gaps, expanding cultural education through association and comparison during the polylogue of Ukrainian and English cultures.

The range of value orientations of students of HEIs significantly expanded due to the instrumental value of "education" and thermal values of "happy family life," "happiness of other people" and "accuracy." Maybe that involvement in a foreign language culture with an emphasis on the comparative intercultural analysis (at the level of language and culture) stimulated the hierarchical structure of thermal and instrumental values of students, promoting their multicultural self-development and self-determination in the world of cultural values, acceptance of the native nation's lifestyle, positive assessment of other national cultures' representatives, readiness for multicultural interaction, dialogue of cultures in a foreign language, self-esteem as a representative of a certain nation, the formation of self-esteem and respect for the dignity of others.

Students of the experimental group were much more aware of the importance of learning a foreign language and entering another culture while professional training $(84 \%$ and $59 \%$ in EG versus $27 \%$ and $16 \%$ in CG at the control stage of the experiment). The students began to express their interest in the values, customs, traditions and lifestyle of a foreign culture. Most students abandoned the stereotypes about other cultures, ideas about people of different nationalities. They demonstrated tolerance, a desire for universal values and dialogue in a multiethnic, multinational and multireligious world; showed readiness for a global exchange of values, ideas and dialogue of cultures.

Simultaneously with the internal motivation of cognitive activity, positive dynamics was observed in the development of multicultural competence of students of the experimental group: understanding of the axiological value of the English language, its importance for future professional activity; awareness that the English language, as well as Ukrainian, is a mechanism for discovering the world around us, acquiring new professional knowledge, provides fluent communication and exchange of experience with foreign colleagues, allows a HEI's graduate to become a competitive specialist; the desire for mutual understanding, global and cosmopolitan exchange of values, ideas and dialogue of cultures, etc. 
If at first students did not clearly understand the essence and content of the multicultural competence, then by the end of the experiment the number of students who independently determined this competence and realised its importance increased. Most of the students named sociability, tolerance, knowledge of a foreign language, understanding of its axiological value, its importance in future professional activities, as well as a view of the language of international communication as a mechanism for discovering the world.

To diagnose the cognitive-gnoseological component, we also used test tasks to understand the importance of multicultural competence and a foreign language in the professional activity. Students answered the questions: "What are the tasks of multicultural education?", "How can we describe the concept of 'youth subculture'?", "What is the dialogue of cultures?", "What is cultural identity?", "What are the problems of mutual understanding?", "When does a person have intercultural sensitivity?", "How do monochrome cultures differ from polychrome ones?", "What is the essence of professional and multicultural competence?". The answers were assessed from 1 to 5 points. If at the determinative stage 38 students of the control group ( 245 people) received a grade of " 5 scores," which amounted to $15.5 \%$, then at the end of the experiment 74 students (30.2\%) received a grade of " 5 scores." Before the formative stage in the experimental group of 251 students, only $36(14.3 \%)$ showed the highest result, and at the control stage - $184(73.3 \%)$ students, which is $59 \%$ more.

Comparing the indicators of the operation-effective component (see Table 2) of the students' multicultural competence, we also found significant positive changes in their readiness to establish a constructive dialogue of cultures by means of a foreign language, cognitive activity, personal attitude to the national community, willingness to speak a foreign language, tactfulness, tolerance, empathy.

The numerical data are presented in Table 2.

Table 2

Levels of students' multicultural competence by the operation-effective component in the process of the formative stage of the experiment

\begin{tabular}{|c|c|c|c|c|c|c|c|c|c|c|c|c|}
\hline \multirow[b]{3}{*}{ Group } & \multicolumn{4}{|c|}{ Fragmentary } & \multicolumn{4}{|c|}{ Situational } & \multicolumn{4}{|c|}{ Stable } \\
\hline & \multicolumn{2}{|c|}{ Before } & \multicolumn{2}{|c|}{ After } & \multicolumn{2}{|c|}{ Before } & \multicolumn{2}{|c|}{ After } & \multicolumn{2}{|c|}{ Before } & \multicolumn{2}{|c|}{ After } \\
\hline & \begin{tabular}{|c|} 
Stu- \\
dents
\end{tabular} & $\%$ & $\begin{array}{c}\text { Stu- } \\
\text { dents }\end{array}$ & $\%$ & $\begin{array}{c}\text { Stu- } \\
\text { dents }\end{array}$ & $\%$ & $\begin{array}{r}\text { Stu- } \\
\text { dents }\end{array}$ & $\%$ & \begin{tabular}{|c|} 
Stu- \\
dents
\end{tabular} & $\%$ & $\begin{array}{c}\text { Stu- } \\
\text { dents }\end{array}$ & $\%$ \\
\hline CG & 142 & 57.3 & 121 & 48.9 & 47 & 19.1 & 61 & 24.7 & 58 & 23.6 & 65 & 26.4 \\
\hline EG & 154 & 61.8 & 38 & 15.4 & 39 & 15.8 & 86 & 34.2 & 56 & 22.4 & 125 & 50.4 \\
\hline
\end{tabular}

Source: own research.

After experimental training, it can be stated that the leading motives in EG are cognitive and communicative. The conclusion about the increase in a number of students with stable and situational levels of the operation-effective component of the multicultural competence has been suggested. The students 
have mastered certain social and cultural norms of communicative behaviour, rules of communication, the ability to operate with multicultural knowledge, the ability to regulate their behaviour in accordance with the rules generally accepted in a foreign language culture. Students learned to follow social norms and rules. The number of students with high and medium levels of empathy has increased.

The analysis of the results revealed that in the experimental groups the number of students who showed a fragmentary level decreased significantly (by $46.4 \%$ ). In the control groups, this indicator changed by only $8.4 \%$. It is worth noting that the change in the number of students at the stable level in the control group is only $2.8 \%$ against $28 \%$ in the experimental group.

Teaching a foreign language on the basis of the developed pedagogical technology of forming students' multicultural competence positively influenced internal motivation of educational activity of students and growth of professionally significant personal qualities. Addressing their subjective experience of intercultural interaction, introduction of new multicultural knowledge with a focus on practice, research work with various information sources gave the classes a creative character. All these factors allowed taking into account the various motivational incentives of students within the educational process, focusing them on self-development in the chosen subject area.

Positive changes in the indicators of personality (Table 3 ) and motivational-value (Table 4) components were achieved in both groups. However, the use of different ways of intensifying educational and cognitive activities in accordance with the level of students' preparation, encourage them to conduct independent creative activity, support feedback, use tasks which develop reflection - all this in combination enabled to achieve a higher level of intrinsic motivation to study and use a foreign language for professional purposes in situations of multicultural interaction.

Table 3

Levels of students' multicultural competence by the personality component in the process of the formative stage of the experiment

\begin{tabular}{c|c|c|c|c|c|c|c|c|c|c|c|c}
\hline & \multicolumn{4}{|c|}{ Fragmentary } & \multicolumn{4}{c|}{ Situational } & \multicolumn{4}{c}{ Stable } \\
\hline \multirow{2}{*}{ Group } & \multicolumn{2}{|c|}{ Before } & \multicolumn{2}{|c|}{ After } & \multicolumn{2}{c|}{ Before } & \multicolumn{2}{c|}{ After } & \multicolumn{2}{c|}{ Before } & \multicolumn{2}{c}{ After } \\
\cline { 2 - 19 } & $\begin{array}{c}\text { Stu- } \\
\text { dents }\end{array}$ & $\%$ & $\begin{array}{c}\text { Stu- } \\
\text { dents }\end{array}$ & $\%$ & $\begin{array}{c}\text { Stu- } \\
\text { dents }\end{array}$ & $\%$ & $\begin{array}{c}\text { Stu- } \\
\text { dents }\end{array}$ & $\%$ & $\begin{array}{c}\text { Stu- } \\
\text { dents }\end{array}$ & $\%$ & $\begin{array}{c}\text { Stu- } \\
\text { dents }\end{array}$ & $\%$ \\
\hline CG & 82 & 33.3 & 107 & 43.4 & 120 & 48.7 & 99 & 39.9 & 45 & 18 & 41 & 16.7 \\
EG & 103 & 41.2 & 13 & 5.3 & 132 & 52.9 & 96 & 38.4 & 14 & 5.9 & 140 & 56.3 \\
\hline
\end{tabular}

Source: own research.

The results of the formative stage of the pedagogical experiment confirm that the number of students in EG, who demonstrate a high level of internal motivation for learning (stable level), increased by $39.2 \%$. The number of students with the stable level of intrinsic motivation increased by $1.7 \%$ in the CG. 
In EG we also observe a decrease in the number of respondents with a fragmentary level of motivation by $44,8 \%$, while in CG - by $8,6 \%$ (Table 4 ).

Table 4

Levels of students' multicultural competence by the motivational-value component in the process of the formative stage of the experiment

\begin{tabular}{c|c|c|c|c|c|c|c|c|c|c|c|c|c}
\hline Levels & \multicolumn{4}{c}{ Fragmentary } & \multicolumn{1}{c}{ Situational } & \multicolumn{4}{c|}{ Stable } \\
\hline \multirow{2}{*}{ Group } & \multicolumn{2}{|c|}{ Before } & \multicolumn{2}{c}{ After } & \multicolumn{2}{c}{ Before } & \multicolumn{2}{c|}{ After } & \multicolumn{2}{c}{ Before } & \multicolumn{2}{c}{ After } \\
\cline { 2 - 13 } & $\begin{array}{c}\text { Stu- } \\
\text { dents }\end{array}$ & $\%$ & $\begin{array}{c}\text { Stu- } \\
\text { dents }\end{array}$ & $\%$ & $\begin{array}{c}\text { Stu- } \\
\text { dents }\end{array}$ & $\%$ & $\begin{array}{c}\text { Stu- } \\
\text { dents }\end{array}$ & $\%$ & $\begin{array}{c}\text { Stu- } \\
\text { dents }\end{array}$ & $\%$ & $\begin{array}{c}\text { Stu- } \\
\text { dents }\end{array}$ & $\%$ \\
\hline CG & 132 & 53,3 & 110 & 44,7 & 97 & 39,3 & 114 & 46,2 & 18 & 7,4 & 23 & 9,1 \\
EG & 138 & 55,4 & 26 & 10,6 & 96 & 38,7 & 110 & 44,3 & 15 & 5,9 & 113 & 45,1 \\
\hline
\end{tabular}

Source: own research.

After analysing the answers to the questions about the preservation of the national culture's elements, we can state that after the formative stage in EG more students began to show interest in folk traditions and customs (before the experiment $-8.4 \%$, and after $-45.8 \%$ ).

Having averaged the values of the levels of students' multicultural competence for all components, we obtained the following results in Table 5.

Table 5

Systematized experimental results of levels of the components of students' multicultural competence for the period of pedagogical experiment (\%)

\begin{tabular}{c|ccccccc}
\hline Components & Levels & \multicolumn{2}{c}{ Fragmentary } & \multicolumn{2}{c}{ Situational } & \multicolumn{2}{c}{ Stable } \\
\cline { 2 - 8 } & Group & Beginning & End & Beginning & End & Beginning & End \\
Cognitive- & CG & 71.6 & 58.7 & 24.3 & 33.8 & 4.1 & 7.5 \\
gnoseological & EG & 73.8 & 11.8 & 22.5 & 52.3 & 3.7 & 36.1 \\
Operation- & CG & 57.3 & 48.9 & 19.1 & 24.7 & 23.6 & 26.4 \\
effective & EG & 61.8 & 15.4 & 15.8 & 34.2 & 22.4 & 50.4 \\
Personality & CG & 33.3 & 43.4 & 48.7 & 39.9 & 18 & 16.7 \\
& EG & 41.2 & 5.3 & 52.9 & 38.4 & 5.9 & 56.3 \\
Motivational- & CG & 53.3 & 44.7 & 39.3 & 46.2 & 7.4 & 9.1 \\
value & EG & 55.4 & 10.6 & 38.7 & 44.3 & 5.9 & 45.1 \\
In general & CG & 53.9 & 47.1 & 32.8 & 37.4 & 13.3 & 15.5 \\
& EG & 59.3 & 12.3 & 26.9 & 39.6 & 13.8 & 48.1 \\
\hline
\end{tabular}

Source: own research.

The analysis of the results of the experimental research on forming students' multicultural competence in the process of professional training indicates the dominance of the opinion among the CG students that a foreign language is 
only a means of communication, essential for professional growth of professionals (73\%). In the EG, $94 \%$ of students agreed that a foreign language is not only an important means of communication, but also a tool for professional activity and a way of cultural self-development. They became more willing to use a foreign language without fear of making a mistake, unlike the CG students, where language and cultural barriers were still high, and only $17.9 \%$ were able to overcome them. This gap clearly demonstrated the discrepancy in the results of the educational process in the control and experimental groups. In CG, the educational process was organised according to the plan focused on mastering the basics of grammar, grammar exercises, using adaptive, outdated texts. The leading type of speech activity was reading. Psychological, pedagogical, linguistic and cultural peculiarities were not taken into account while teaching a foreign language for the students. Grammar-translation method of teaching prevailed.

The process of the multicultural education of EG students at foreign language classes involved the use of various authentic materials which contained interesting information about other countries and cultures, about Ukraine; teacher's talks; conversation with the teacher; performance of various tasks, tests; modelling a dialogue of cultures; use of multimedia tools. Interactive teaching methods helped to immerse the EG students immediately in foreign language activities, regardless of the level of their foreign language proficiency and multicultural knowledge.

In contrast to the results of the determinative diagnostics, where the students preferred mostly one of the four types of speech activity, in the control phase of the experiment most EG students showed confidence in several types of speech activity (listening, reading, speaking, writing), but far only one type of speech activity dominated in the CG. Positive changes are related to the recognition by the EG students of such types of work as creative task (project, role play, modelling of socio-cultural situations, interactive dialogue, etc.). Creative tasks contributed to the development of a student's multicultural personality, which covered cognitive, motivational, value, personal, activity aspects and took place not on the basis of other people's social experience, but by independent acquisition of cultural, spiritual, moral, national, aesthetic values. $74.1 \%$ of the EG students noted that they "discovered a potential that they had not previously guessed until they began to solve creative problems." In their opinions, creative tasks:

- developed a willingness to change roles constantly due to the need for active socialisation and professional mobility in today's multicultural world;

- created opportunities to take an initiative position in the educational process;

- allowed to find out more about the features of the national identity of the native and foreign countries' cultures;

- focused not only on the study of a foreign language as a discipline, but also the features of linguistic culture; 
- provided an opportunity to participate in the dialogue of cultures by forming new values, new meanings in the understanding of foreign phenomena;

- stimulated readiness for mutual understanding between people, which contributed to the preservation of the identity of cultures, the establishment of multicultural interaction in the practical work abroad;

- contributed to the readiness to become a mediator between the native and foreign cultures, to demonstrate examples of foreign experience in their culture, expanding intercultural contacts.

In addition to creative tasks, according to students' thoughts, informative, meaningful original texts, communicative tasks (text translation; description of people, objects, situations, events; expression of personal attitudes to a certain fact; composing dialogues, etc.), ways of presenting grammatical material, which contributed to the faster assimilation of new socio-cultural material; verbal supports that depicted various objects, diagrams, tables; work with authentic materials taking into account the concept of "cultural context," introduction of the author's electronic educational methodological complex of forming students' multicultural competence have proved their efficiency.

The students believe that socio-cultural and foreign language skills: allows to continue professional training abroad (33.9\% in CG, 60\% in EG); help to get a job abroad (51.8\% in CG, $76 \%$ in EG); enable participation in international cooperation (42.8\% in CG, $68.1 \%$ in EG); give the opportunity to master another / related profession (11.8\% in CG, 53.8\% in EG); do not affect the development of agricultural professionalism (24\% in CG, $6 \%$ in EG); Successful learning of a foreign language involves not only studying a language but also socio-cultural peculiarities, cultural diversity of the modern multicultural world with its help (17.1\% in CG, 94\% in EG).

Answers to the question of the purpose of learning a "foreign language" indicate that in general, students of CG (to a lesser extent) and EG have changed their attitude to this discipline. At the same time, new positions appeared in the experimental group: "Be able to interact constructively with foreign colleagues;" "Process information systematically;" "Be able to conduct a dialogue of cultures;" "Study the experience of doing business correspondence;" "Learn to discuss freely in a foreign language." The EG also did not show indifference to multicultural and foreign language skills.

Answering the question "In your opinion, what has been done in the process of teaching a foreign language to master multicultural knowledge better and encourage active participation in the pedagogical process?" the answers in the EG were arranged as follows: professionally-oriented authentic texts were used from the very beginning of the study; the communicative situations of another socio-cultural reality were expanded; grammatical material was explained on the basis of socio-cultural and linguistic texts; multicultural information was added; active teaching methods (creative tasks that allow expressing one's own opinions; thematic improvisation; reports, etc.) were introduced; the informativeness of educational materials was increased; various forms 
of presentation of educational materials by the teacher; the stage of adaptation was taken into account during the submission of professionally-oriented materials for the organisation of effective independent work; creative works (compositions, essays, reports, business letters, etc.) were written; the principle of co-creation of teachers and students was implemented, that facilitated the exchange of knowledge, values and ways of learning about the surrounding multicultural world, the educational environment became democratic and got personal significance; training was considered as a process of integration of language and culture, which allowed future professionals to coordinate the implementation of values, ideas, assessments, patterns of native and foreign cultures' behaviours; understanding of a foreign language as an important tool and means of professional and cultural growth.

Besides the components required for effective multicultural interaction by means of a foreign language, in addition to the knowledge of vocabulary and grammar of a foreign language, the ability to model situations of cultural dialogue creatively, linguistic intuition, the ability to navigate in a cultural context; reflection, critical thinking, self-development, the EG students also singled out motivation, self-actualisation, the ability to interpret, the ability to share information and experience; ability to improvise, imagination, dialogic thinking, the ability to navigate in extralinguistic contexts, the multicultural worldview, willingness to expand the value system, empathy, tolerance.

Regarding the statement "Ukraine is...," at the control stage of the pedagogical experiment the CG and EG students expressed the following opinions: "civilisation in itself" - supported by $17.8 \%$ of CG and $4 \%$ of EG; "the part of the Western civilisation" - 27.2\% and 13.4\%; "more Eastern state" $-17.1 \%$ and 7.5\%; "The bridge between East and West" - 11.8\% and 72.1\%; 26.1\% and 3\% could not answer.

From the analysis of the results of the formative stage of the experiment it follows that: Ukraine as a self-sufficient system is considered by 1.5 times less than CG students against EG students; in CG the number of students who consider Ukraine a part of Western and Eastern civilisation has increased (1.5 and 1.4 times), in contrast to EG, where their number decreased by 1.3 and 1.6 times, respectively (in EG compared with CG figures are smaller, respectively, in 2 and 2.28 times); Ukraine as a bridge between East and West in the CG is considered by 1.3 times more, and in the EG - 8 times more students; more students began to think about Ukraine's place in the modern multicultural world - 1.3 times more CG students and 11.3 times more EG students (8.7 times more EG respondents than CG students).

Of the proposed theses, which reflect the essence of modern culture, the students preferred the following: "creating a single world culture" (CG - 9\%, EG - 2\%), "preservation/revival of the culture's 'roots' and the impossibility of innovation" (CG - 21\%, EG - 3\%), "consideration of our culture as a benchmark with which we compare other cultures" (CG-16\%, EG-1\%), "respect for other cultures' values" (CG - 51\%, EG - 94\%), "process of cultural exchange" (CG - 62\%, EG - 100\%), "convergence of different cultural values" (CG - 16\%, 
EG - 97\%), "the need for cultural renewal, adaptation to new realities in life" (CG - 38\%, EG - 91\%).

Having processed the obtained results, we came to the conclusion that the responses of CG students at the determinative and control stages of the experiment did not change significantly, but ranged from 1-4\%, while changes in EG students reached 17-55\%. In EG, in comparison with CG, 4 times less students realised the importance of creating a single world culture; the impossibility of innovation in the culture - 7 times less; the number of students who believe that their culture should be considered as a benchmark for other cultures decreased by $13 \%$; the number of students who showed respect for other cultures' values increased by 1.7 times; 1.5 times more students gained confidence in the need for the process of cultural exchange; 6.1 and 5.7 times more students recognised the importance of converging values; 2.4 and 2.3 times more acknowledged the need in cultural renewal. The statement "I'm only interested in my specialty" was noted by $18 \%$ of CG and 3\% of EG, which is 0.1 times and 6 times less than at the determinative stage of the experiment.

The results of processing the results of the questionnaire revealed changes in the scale of values in CG and EG. The CG students were not sufficiently oriented for self-development (5\%). 84\% of CG students put forward prestige, financial status, career in the first place rather than the desire for creativity, achievements. They did not show a desire to meet spiritual needs, cultural self-development, and preservation of individuality.

As for the EG students, we observe a positive tendency: for $76 \%$ of students such concepts as creativity, self-development, satisfaction of spiritual needs, preservation of individuality, social contacts have become equally important. Only $16 \%$ of students put their own prestige, financial status and satisfaction in the first place in the system of values. $8 \%$ of students admitted that the future profession is not important for them. 3\% consider family well-being to be the most important. 5\% are sure that they will not work in the profession.

Cognitive abilities of students with the fragmentary level are underdeveloped. They do not have the ability to overcome the deficit of multicultural and foreign language knowledge, concepts, skills and abilities. Verbal intelligence, language memory, communicative intuition, the ability to enter a new cultural environment and multicultural potential are weak.

As for students with the situational level of the multicultural competence, their cognitive abilities are quite well developed. Although the ability to overcome the deficit of multicultural knowledge, concepts, skills and abilities is already formed, their basic cognitive structures, perception and understanding of the language and world of another socio-cultural community are unclear. The development of multicultural interaction skills can be described as average. They respect the customs of ethnophores and function successfully in multicultural realities.

For students with the stable level of the multicultural competence deep awareness of the axiological and professional value of a foreign language 
and its importance in professional activities are typical. Students fully understand that the English language is a mechanism for discovering the surrounding multicultural world, provides a constructive dialogue of cultures, which will allow HEIs' graduates to become competitive professionals in the labour market. Their perception and understanding of the multicultural environment are clearly expressed, which indicates a high level of the cognitive-gnoseological component. They are able to communicate fluently in a foreign language with ethnophores, showing respect for foreign customs.

Thus, the results of the formative and control stages have verified the efficiency of the pedagogical technology of forming students' multicultural competence. The expediency of realising the grounded pedagogical conditions has been proved. The dynamics of the process of forming students' multicultural competence in the process of professional training is presented in Table 5. The levels of the students' multicultural competence of according to four criteria, the diagnostics of which was carried out at the determinative and control stages of the experimental research, are given.

From the EG students' viewpoints, the implementation of pedagogical technology of forming students' multicultural competence at foreign language classes has contributed to the development of their readiness to:

- adequate implementation of the transfer and receipt of relevant information about the surrounding multicultural world;

- operation of a wide language thesaurus;

- verbalisation of the professional culture's processes and phenomena;

- the study of a foreign language and national peculiarities of the countries with whose representatives they are going to interact during foreign internships, production practice, development of joint research projects, international conferences, etc.;

- a flexible response to ambiguous, rapidly changing situations of real communication, because culture does not exist as a frozen form, but as a process;

- development of their professional activity's most important aspects - agricultural, production, creative, organisational, educational, communicative (speech skills of a monologue, dialogue, logical-semantic operations);

- creative realisation of own individuality in professional and socio-cultural activity;

- dialogue of cultures in order to enrich the general cultural potential in the performance of their professional duties.

The results during the EG's survey indicated that students began to consider multicultural and foreign language knowledge as a tool for self-development, self-actualisation, self-affirmation, self-determination, and foreign language learning was associated not only with grammar, semantics, stylistics, but also with intellectual, value, motivational, multicultural development of a personality.

The students noted that they had caught an idea of how to behave for preventing intercultural misunderstandings. Students take a positive view of the 
participation in cooperation with foreign colleagues during foreign workshops, practice, internships, joint projects, because, in their opinion, the exchange of experience promotes professional growth. In turn, the students admitted that their professional activities were more effective, and temporary psychological barriers in there multicultural interaction were minimised, taking into consideration: the obtained necessary socio-cultural information for successful communication with a representative of a foreign country; avoidance of sudden judgments and decisions in the process of intercultural communication; ability to analyse one's thoughts and actions through the prism of an observer, critical attitude to stereotypes; openness to different views; discussion on the principle of cooperation, taking into account the cultural characteristics of people in the context of their work, speech culture, professional ethics, understanding of time and space, linguistic differences, reactions to the hierarchy of relationships and differences in values.

The analysis of the research results also confirmed the importance of motivation in involving students in the process of interactive teaching. This process was built on revealing the significance of the discipline "Foreign Language" in the framework of its practical and professional orientation, which enabled building a creative atmosphere in the classroom, aroused a research interest in various aspects of multicultural education. As for the system of values of the CG students, it did not undergo significant changes in general. At the same time, the system of values of the EG students changed in the following: the development of abilities to carry out multicultural interaction with the help of a foreign language; gaining access to various resources and forming a willingness to use authentic information for professional and personal growth; expanding the picture of the world; self-awareness as a multicultural personality, an integral part of the socio-cultural space.

The efficiency of implementing of the pedagogical technology of forming students' multicultural competence has been proved with the methods of mathematical statistics. We observe positive dynamics in the main indicators of cognitive-gnoseological, motivational-value, personality and operationeffective components of the multicultural competence. In the research process the following methodical recommendations for foreign language teachers have been developed:

- the study of a foreign language on authentic socio-cultural material contributes to the formation of an internationally oriented personality with a developed sense of tolerance, socio-cultural observation, empathy; who understands and perceives cultural diversity; who retains national and cultural identity and is ready for multicultural interaction in the multifaceted social relations of the modern world;

- comparative linguistic analysis makes it possible to identify not only common, universal, but also to understand the specifics of native culture and analyse the multicultural reality;

- socio-cultural equipping of the content of foreign language teaching develops an individual's multicultural potential; 
- extracurricular activities increase the students' internal motivation to study the foreign language, cultural values of different countries, enrich future professionals spiritually and culturally;

- involvement of students in scientific-cognitive and project activities significantly intensifies the classroom and independent work of future specialists;

- skilfully selected forms, techniques and methods of work, a successful combination of educational and pedagogic activities play a decisive role in shaping a personality's multicultural potential.

In pedagogical and psychological researches it is often necessary to find out whether the general populations from which the samples have been taken differ. For example, the differences between the experimental and control groups of students in terms of academic performance are taken into consideration while applying various teaching methods. Methods for testing statistical hypotheses about sample homogeneity can be implemented on the basis of parametric and nonparametric criteria for independent and dependent samples. Thus, hypotheses about the homogeneity of samples are hypotheses about the similarity or difference of two or more samples. Let us have a look at the results of calculating $t_{\text {ex }}$ criterion for each component given in Table 6 (Barkovskyi, Barkovska, \& Lopatin, 2010).

In accordance with the table of Student's t-test at degrees of freedom 496 and the highest level of significance of 0.01 table (critical) value $t_{c r}=2.586$, and the obtained values for each component are higher than the table values, indicating significant differences in the levels of students' readiness for professional activity.

The results of experimental work confirmed the importance of educational work in the process of forming students' multicultural competence at foreign language classes. As shown in Table 5 and Table 6, in the experimental group more students reached the stable level of the multicultural competence, which involves the possession of communicational foreign language skills and communication culture in the field of professionally oriented communication, the use of multicultural knowledge in solving practical problems of intercultural communication, the ability to model the communicative behaviour depended on the external context and position of the interlocutor. In the CG, most students demonstrated the situational level of the multicultural competence, which implies a certain amount of knowledge of geography and culture of the country whose language is studied, the ability to obtain information from various sources of sociocultural nature and using it in professional activities or self-education, basic communication strategies and norms of the communication culture. To increase the reliability of interpretations we observed the educational activities and behaviour of students during the experiment repeatedly and systematically; the observations were made by several people; individual facts and actions of students during the process of organising and conducting the experiment was factually recorded. 
Table 6

Results of calculating Student's t-test

\begin{tabular}{|c|c|c|c|c|c|c|c|c|c|c|c|}
\hline \multicolumn{2}{|c|}{ Groups } & \multirow{3}{*}{ GPA } & \multicolumn{9}{|c|}{ Indicators used for the calculation of Student's criterion } \\
\hline \multirow{2}{*}{$\begin{array}{l}\text { CG } \\
\mathrm{EG}\end{array}$} & \multirow{2}{*}{$\begin{array}{l}247 \\
249 \\
\end{array}$} & & \multicolumn{3}{|c|}{ Levels } & \multirow[b]{2}{*}{3} & \multirow[b]{2}{*}{4} & \multirow[b]{2}{*}{5} & \multirow{2}{*}{$\sum_{i=1}^{k}\left(x_{i}-x_{j}\right)^{2}$} & \multirow[t]{2}{*}{$\mathbf{D}$} & \multirow{2}{*}{$\begin{array}{c}t_{\text {cr. }}=2.586 \\
t_{\text {ex. }}\end{array}$} \\
\hline & & & 3 & 4 & 5 & & & & & & \\
\hline \multicolumn{12}{|c|}{ Cognitive-gnoseological component } \\
\hline & G & 3.49 & 145 & 83 & 19 & 0.49 & -0.51 & -1.51 & 13.161 & 6.554 & \multirow{2}{*}{3.676} \\
\hline & G & 4.24 & 29 & 130 & 90 & 1.24 & 0.24 & -0.76 & 7.731 & 3.881 & \\
\hline \multicolumn{12}{|c|}{ Operation-effective component } \\
\hline & G & 3.77 & 121 & 61 & 65 & 0.77 & -0.23 & -1.23 & 9.555 & 4.758 & \multirow{2}{*}{3.051} \\
\hline & G & 4.35 & 38 & 86 & 125 & 1.35 & 0.35 & -0.65 & 8.070 & 4.051 & \\
\hline \multicolumn{12}{|c|}{ Personality component } \\
\hline & G & 3.73 & 107 & 99 & 41 & 0.73 & -0.27 & -1.27 & 9.955 & 4.957 & \multirow{2}{*}{3.960} \\
\hline & $G$ & 4.51 & 13 & 96 & 140 & 1.51 & 0.51 & -0.49 & 9.081 & 4.559 & \\
\hline \multicolumn{12}{|c|}{ Motivational-value component } \\
\hline & G & 3.65 & 110 & 114 & 23 & 0.65 & -0.35 & -1.35 & 10.870 & 5.413 & \multirow{2}{*}{3.490} \\
\hline & $G$ & 4.33 & 26 & 110 & 112 & 1.33 & 0.33 & -0.67 & 7.987 & 4.010 & \\
\hline
\end{tabular}

In order to determine the efficiency of the pedagogical technology of forming students' multicultural competence, we compared the results of control sections on different topics in the EG before and after the experiment, subjected the data to processing using the methods of mathematical statistics (Barkovskyi, Barkovska, \& Lopatin, 2010), for example, on the topic of "British Customs and Traditions" (Table 7).

Table 7

The results of the control test on the topic "British Customs and Traditions" in the EG

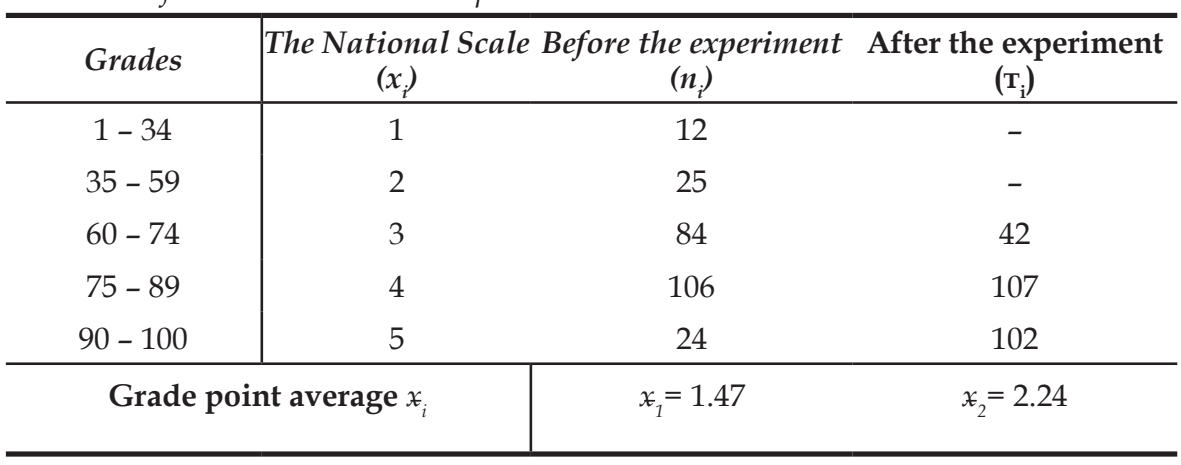


We use the criterion of truth to determine the success of students' mastery of this topic before and after the experiment.

Let us test the null hypothesis $\mathrm{H}_{0}$, according to which there are no differences between the estimates before and after the application of the experimental method.

According to the laws of mathematical statistics, if the number $Z<3$, then the null hypothesis must be accepted.

In our case, $Z=12.4>3$ this means that the null hypothesis must be rejected, i.e. the difference in success on this topic is obvious.

We conducted similar research while studying other topics, and each time the calculated value $Z$ significantly exceeded 3 . Thus, we could conclude about the significant positive didactic effect of the proposed experimental pedagogical technology.

Table 8 presents the general dynamics of statistical characteristics of the students' multicultural competence by all four criteria: cognitive-gnoseological, motivational-value, personality and operation-effective before and after the experiment.

On the basis of the obtained results, it can be stated that the developed pedagogical technology of forming students' multicultural competence is quite effective and has a significant positive impact. Before the experiment, the stable level of the multicultural competence was diagnosed in 13,8\% of students, situational - in $26.9 \%$, fragmentary - in 59.3\%, and after the experiment the stable level - in $48.1 \%$, situational - in 39.6\% and fragmentary - in $12.3 \%$, respectively. In other words, the number of students with the stable (by 34.3\%) and situational (by 12.7\%) levels of the multicultural competence in the EG has significantly increased, the number of students with the fragmentary level has decreased (by $47 \%$ ).

Table 8

General dynamics of the development of students' multicultural competence before and after the experiment $(\%)$

\begin{tabular}{c|cccccc}
\hline Levels & \multicolumn{2}{|c}{ Fragmentary } & \multicolumn{2}{c}{ Situational } & \multicolumn{2}{c}{ Stable } \\
\hline Group & Before & After & Before & After & Before & After \\
CG & 53.9 & 47.1 & 32.8 & 37.4 & 13.3 & 15.5 \\
EG & 59.3 & 12.3 & 26.9 & 39.6 & 13.8 & 48.1 \\
\hline
\end{tabular}

Source: own research.

We compared the results of the grade point average by four components in the CG and EG before and after the formative stage of the experiment and saw that the obtained grade point average had not changed $\left(\bar{y}_{2}=1,68\right.$ vs. $\left.\bar{y}_{1}=1,59\right)$, while in the EG before the experiment the grade point average was $\bar{x}_{1}=1.54$, and after the experiment $\bar{x}_{2}=2.36$, i.e. increased by $0.82(53.2 \%)$.

It was proved by the methods of mathematical statistics that the results in the EG had improved after the applied author's pedagogical technology. 
The ratio of levels of the CG and EG students' multicultural competence before and after the experiment is presented in the form of graphs (Fig. 3, Fig. 4).
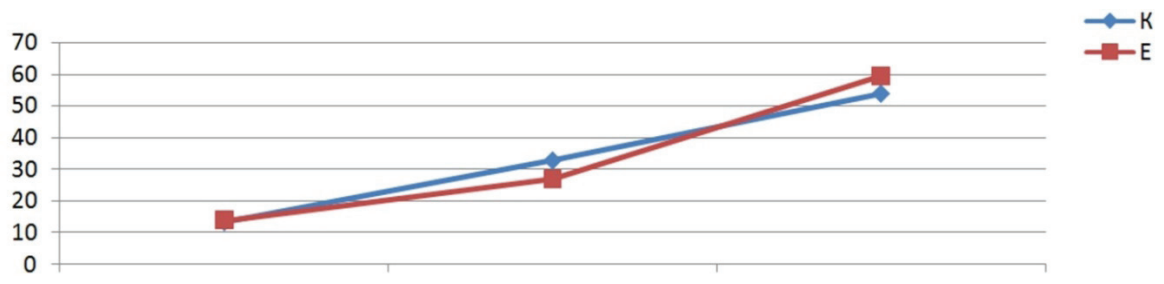
Stable level
Situational level
Fragmentary level

Fig. 3. Ratio of the CG and EG students before the experiment.

Source: own research.

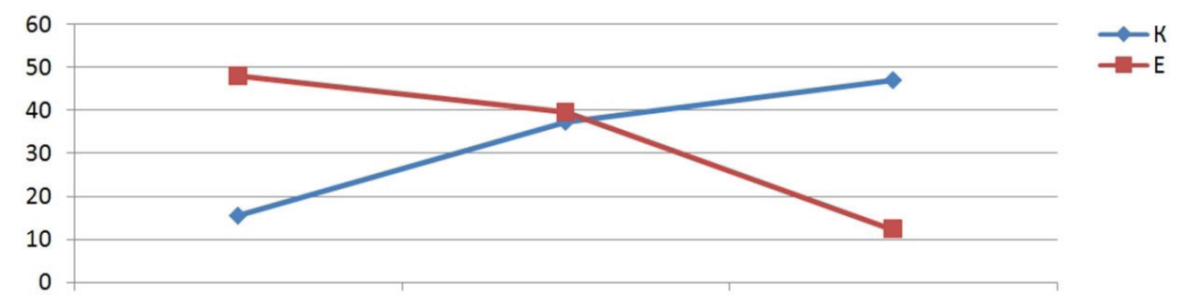

Stable level

Situational level

Fragmentary level

Fig. 3. Ratio of the CG and EG students after the experiment.

Source: own research.

From the given above graphs, it is obvious that before and after the curve, which corresponds to the CG, has hardly changed; the curve, which corresponds to the EG has changed markedly: the rate corresponding to a stable level has significantly increased, and the rate corresponding to the fragmentary level has decreased.

The overall growth rate of the students' multicultural competence was determined by calculating the total value of the increase in the CG and EG, collating and comparing the grade point average at the beginning and at the end of the experiment.

Thus, in the CG students about the achieved with the help of traditional education intensity of the development of the multicultural competence can be judged from the analysis of the ratio of averages (before the experiment) and (after the experiment):

$$
\mathrm{K}_{\mathrm{K}}=\frac{\bar{y}_{2}}{\bar{y}_{1}}=\frac{1,68}{1,59} \approx 1,06
$$

Regarding the ratio of the grade point average of EG $\left(\mathrm{K}_{\mathrm{e}}\right)$, we observe that the dynamics of growth $\left(\bar{x}_{1}\right.$ - before the experiment, $\bar{x}_{2}$ - after the experiment) is much better than in CG: 


$$
\mathrm{K}_{\mathrm{e}}=\frac{\bar{x}_{2}}{\bar{x}_{1}}=\frac{2,36}{1,55} \approx 1,52
$$

The calculation of the coefficient of relative growth of the general level of the students' multicultural competence $\left(\mathrm{K}_{\text {res }}\right)$ made it possible to determine the dynamics of socio-cultural qualities in the CG and EG:

$$
\mathrm{K}_{\mathrm{res}}=\frac{K_{e}}{K_{\kappa}}=\frac{1,52}{1,06} \approx 1,43 .
$$

As we can see, the pedagogical technology implemented at the formative stage of the research helped to improve the students' multicultural characteristics. The analysis of the results of this work indicated that before the experiment the groups had belonged to one general sample and after that the indicators in the EG increased significantly. Such positive changes in the multicultural competence of the EG students were achieved by the implementation of our pedagogical technology during the professional training.

\section{CONCLUSION}

The efficiency of the pedagogical technology of forming students' multicultural competence was verified in three stages (determinative, formative, control) from 2012 to 2017. At the determinative stage of the pedagogical experiment we found out the levels of the EG and CG students' multicultural competence: the stable level was diagnosed in $8 \%$ and $13.3 \%$, situational - in $26.9 \%$ and $32.8 \%$, fragmentary - in 59.3\% and $53.9 \%$.

Criteria, indicators and levels of the students' multicultural competence have been defined: the motivational-value component (motivational criterion, indicators: awareness of valuable aspects of professional activity; aspiration to develop new knowledge, skills and abilities, motivation for self-improvement of multicultural and foreign language skills); the personality component (performance criterion, indicators: internality; tolerance; reflectivity; openness; subjectivity); the cognitive-gnoseological component (semantic-methodological criterion, indicators: intellectual initiative in various speech activities; social knowledge, knowledge of verbal and nonverbal means of communication); the operation-effective component (organisational criterion, indicators: readiness to demonstrate the multicultural competence in professional activities; the ability to conduct a dialogue of cultures; ability to improvise during intercultural communication; adequate interpretation of the ethnophores' behaviour and actions).

The formative experiment involved the implementation of the pedagogical technology of forming students' multicultural competence in compliance with the determined pedagogical conditions (implementing the interactive teaching methods for increasing the internal motivation of educational activity; the organisation of the educational multicultural environment as the social system of a multi-subject type at a higher education institution; improving forms and 
methods of independent work; application of electronic educationally-methodological complex of forming future specialists' multicultural competence).

The experiment was conducted on the basis of the developed pedagogical technology of forming students' multicultural competence with paying attention to three target components: conceptual, substantive, procedural. The author's technology was introduced due to the concept of multicultural education.

The implementation of pedagogical technology in the practice of higher education institutions provided for motivation-organisational, operation-cognitive, diagnostically-oriented, analytical-efficient stages. The essence of experimental teaching reveals itself in organising multicultural education at foreign language classes on the basis of the systemic, acmeological, synergistic, cultural, personality-oriented, competency-based, axiological and communicative approaches, i. e. in multicultural education we can clearly trace the relationship between language and culture; professional orientation; taking into consideration individual psychological, psychophysiological, social characteristics of students; communication orientation of education; authenticity; situationality.

Experimental verification of the efficiency of the proposed pedagogical technology confirms that the realisation of the selected pedagogical conditions makes a positive impact on the level of students' multicultural competence. That was evidenced by diagnostic data before the formative stage of the pedagogical experiment and after it. At the final stage of the formative experiment, according to the results of experimental work, it was found out that the number of the EG students who reached the stable level increased by $34.3 \%$ (from $13.8 \%$ to $48.1 \%$ ), and in the control group - only by $2.2 \%$ (from $13.3 \%$ to $15.5 \%$ ); the number of students with the situational level of the multicultural competence increased by $12.7 \%$ (from $26.9 \%$ to $39.6 \%$ ) in the EG and by $4.6 \%$ (from $32.8 \%$ to $37.4 \%$ ) in the CG; the number of students with the fragmentary level decreased by $47 \%$ (from $59.3 \%$ to $12.3 \%$ ) in the EG and in the control group there was a slight decrease in such students - by $6.8 \%$ (from $53.9 \%$ to $47.1 \%$ ). Thus, the hypothesis is true. The validity of the results has been confirmed by Student's t-distribution test (Barkovskyi, Barkovska, \& Lopatin, 2010; Zhluktenko, Nakonechnyi, \& Savina, 2007). That is, the introduction of the pedagogical technology of forming students' multicultural competence has a positive impact on the outlined process.

The efficiency of implementing the pedagogical technology of forming the multicultural competence is explained by the fact that in the research process the shortcomings in training students for multicultural activities (lack of the education's focus on upbringing a multicultural personality; low level of students' motivation; inadequate use of innovative teaching methods; unclear understanding of multicultural education's role in the individual's spiritual and intellectual self-development) have been overcome. All this has enabled us to determine the pedagogical measures aimed at improving students' multicultural knowledge, skills and capacities, such as: discussions, didactic, business imitation-role games, problematic lectures, lecture-dialogues, lecture-consultations, lecture-visualisation, quizzes, talk shows, round tables, brainstorming, language portfolios, interpretations of works, improvisation, writing creative projects, presentation of abstracts, press conferences, etc. 


\section{REFERENCES}

[1] Bakhtin, M. M. (1986). Aesthetics of verbal creativity. Russia, Moscow: Art.

[2] Banks, J. A. (2006). Cultural diversity and education: Foundations, curriculum and teaching. USA, Boston: Pearson, Allyn, \& Bacon.

[3] Barkovskyi, V. V., Barkovska, N. V, \& Lopatin, O. K. (2010). Probability theory and mathematical statistics. Ukraine, Kyiv: Center of Educational Literature.

[4] Derbenova, A. H. (2012). All about motivation. Kharkiv: Osnova.

[5] Dolzhenko, V. O. (2006). Bringing up the cultural wealth among students' youth in the multicultural space. Ukraine, Luhansk: Volodymyr Dahl East Ukrainian National University.

[6] Fetiskin, N. P., Kozlov, V. V., \& Manuilov G. M. (Eds.). (2002). Socio-psychological diagnostics of personality development and small groups. Moscow: Publishing House of the Institute of Psychotherapy.

[7] Honcharenko, L. A., Zubenko, A. M., \& Kuzmenko, V. V. (2007). Development of secondary school teachers' multicultural competence. Ukraine, Kherson: RIPO.

[8] Ivaniuk, I. V. (2016). Development of the computer-oriented educational environment in the conditions of the multicultural education of pupils in the European Union's countries. Ukraine, Kyiv: The Institute of Pedagogy of NAES of Ukraine.

[9] Karelin, A. A. (Ed.). (2007). Comprehensive encyclopaedia of psychological tests. Moscow: Eksmo.

[10] Kendzor, P. I. (2017). Multicultural education of students in the system of general education schools' activity (theory and methods). Ukraine, Kyiv: NAES.

[11] Kravets, R. A. (2015). Specific principles of multicultural education of future agrarians at foreign languages classes. Science, Technology and Higher Education: Proceedings of the IX international research and practice conference, 99-105.

[12] Kravets, R. A. (2017). Theoretical and methodical bases of the future agrarians' multicultural education. Ukraine, Vinnytsia: Planer.

[13] Kravets, R. A. (2019). Training students for cross-cultural communication at foreign language classes in the context of internationalisation of higher education institutions, Innovative Pedagogy, 14(1), 105-109.

[14] Lynch, J. (1986). Multicultural education: Principles and practices. UK, London: Routledge and Kegan Paul.

[15] Narvaez, D., \& Patrick, H. (2010). The relation of multicultural experiences to moral judgment and mindsets, Journal of Diversity in Higher Education, 1(3), 43-55.

[16] Pochebut, L. H. (2012). Cross-cultural and ethnic psychology. St. Petersburg: Piter.

[17] Rean, A. A. (2001). Practical psychodiagnostics of personality. St. Petersburg: Speech.

[18] Samarina, N. V. (2016). Formation of schoolchildren's competence of foreign language written speech by electronic didactic means [Doctoral Dissertation]. Russia, Nyzhnii Novhorod: Nizhnii Novhorod Dobroliubov State Linguistic University. Retrieved August 5, 2021, from http:/ / www.dslib.net/teoria-vospitania/formirovanie-kompetencii-inojazychnoj-pismennoj-rechishkolnikov-s-pomowju.html.

[19] Soldatova, H., Shaiherova, L., Kravtsova, O., \& Khukhlaieva O. (Eds.). (2008) Psychodiagnostics of personality tolerance. Moscow: Smysl.

[20] Tatarko, A. N., \& Lebedeva, N. M. (2011). Methods of ethnic and cross-cultural psychology. Moscow: Publishing House of the Higher School of Economics.

[21] Vorotniak, L. I. (2008). Peculiarities of the pedagogical technology of forming the multicultural competence of masters at higher pedagogical education institutions, Pedagogical discourse, 3, 48-53.

[22] Vykhrushch-Oleksiuk, O. A. (2016). Personal determinants of integration into the multicultural environment. Ukraine, Severodonetsk: Volodymyr Dahl East Ukrainian National University.

[23] Zhluktenko, V. I., Nakonechnyi, S. I., \& Savina, S.S. (2007). Probability theory and mathematical statistics. Ukraine, Kyiv: KNEU.

[24] Zhorniak, N. E. (2011). Multicultural competence in professional training, Scientific Bulletin of Volyn National University named after Lesia Ukrainka, 7, 41-46. 